\title{
Contributions from the New Rhetoric and Foucault's thought to the teaching of argumentative discourse
}

\section{Isabel Cristina Michelan de Azevedo}

Professor at Federal University of Sergipe (UFS), Brazil.

icmazevedo@hotmail.com

\begin{abstract}
This article draws on the argumentative scheme described by New Rhetoric (PERELMAN; OLBRECHTS-TYTECA, 1971 [1958]), reinterpreted by some notions analyzed by Foucault (1972), to propose criteria that can guide the teaching of argumentative discourse in basic education. Based on the interpretive methodology (ERICKSON, 1986), first, it discusses how rhetorical reasoning by connection and association impacts the composition of discourses in society. Second, it articulates discursive and rhetorical concepts to compose orientations that favor the development of teaching and learning processes aimed at the formation of subjects who can assume positions related to other positions in various social circumstances.
\end{abstract}

Keywords: Argumentative strategies. Teaching and learning process. Discursive procedures.

Resumo: Este artigo se apoia no esquema argumentativo descrito pela Nova Retórica (PERELMAN; OLBRECHTS-TYTECA, 1971 [1958]), reinterpretado por algumas noções analisadas por Foucault (1971), para propor critérios que possam guiar o ensino do discurso argumentativo na educação básica. Com base na metodologia interpretativista (ERICKSON, 1986), primeiramente, discute como os raciocínios retóricos por ligação e associação impactam a composição de discursos na sociedade. Em segundo lugar, articula conceitos discursivos e retóricos para compor orientações que favoreçam o desenvolvimento de processos de ensino e aprendizagem voltados à formação de sujeitos para que consigam assumir posicionamentos relativos a outras posições em variadas circunstâncias sociais.

Palavras-chave: Estratégias argumentativas. Processo de ensino-aprendizagem. Procedimentos discursivos. 


\section{Introduction}

By conceiving discourse in the perspective proposed by Foucault, we understand discursive acts as productions forged by forces that can be identified by a subject, not a priori, but from an analytical movement linked to social events. Thus, we are driven to enquire the accepted values in various spaces and times as well as to suspect apparent evidence. Consequently, we admit that all manifest discourse rests on an "already-said"; and that this "already-said" is not simply an already mentioned statement or an already written text, but a historical and social construction (FOUCAULT, 1972, p. 25).

One makes mistakes, however, by believing that it is a search for a secret, that is to say, an unit of hidden meaning, because it is a responsibility of the analyst to identify the rules that the statements are associated with and obey, in order to assimilate the network of interrelationships between statements. By problematizing the cut-outs, the limits, the differences, the chronological particularities, the unique manners of permanence and resistance, the analyst is able to recognize the possible types of relationship, as well as the system of relationships which the discourses are related to.

Foucault (1972) proposes that each moment of the discourse can be understood as an interruption of an event, situated in a specific spatialtemporal area. It is a temporal dispersion, however it integrates the social stabilities, values, habits, marks of social structures, etc. Following the principle of regularity, we can observe what can be manifested, known or transformed, erased, because the discursive fact is a discontinuous practice, but it intersects with others and, sometimes, ignores or excludes itself. This movement is constitutive of the discourse, therefore it is crucial to comprehend an event as in its singularity as in its dispersal.

Bearing this in mind, when we are concerned with the development of the argumentative discourse, we seek support in a conception that could dialogue with Foucault concepts, to bring about a critical examination of the role of the evidence in the construction of thinking, in order to break with the non historical character and the fragmented knowledge. Based on Perelman theory (1982 [1977]), who proposes the study of argumentative links both from the perspective of association and dissociation of elements, grounded on a philosophy of the reasonable, which does not dichotomize or disconnects 
regimes of power and thought, we intend to comprehend, variously, the concept of correlation, guided by the principle of the argumentative reasoning (GRÁCIO, 1992).

When constituting the New Rhetoric, Perelman and Olbrechts-Tyteca (1971 [1958], p. 1) defined that "the domain of argumentation is that of the credible, the plausible, the probable". That is why it occurs in the relationship between subjects and ideas, from previous ways of saying, which are not justified by themselves, but are always an effect of a construction whose rules must be recognized based on the analysis of its constitution when one intends to produce meanings.

Therefore, we decide to revise the types of arguments arranged by Perelman and Olbrechts-Tyteca (1971 [1958]), submitting them to the coercion imposed by the discourse, in accordance with Foucault (1972), in order to evaluate, initially, how these relationships can guide pedagogical practices of teaching argumentation in Portuguese language classes for students of basic education.

For this purpose, we will follow an interpretative methodological perspective, due to the fact that, in agreement with Erickson (1986), we admit that subjects create meaningful interpretations about the objects of knowledge and of the experiences and, consequently, they create realities from which the social practices of which they take part in organize themselves, both in the observation of the practices that may have space in the school and in the articulation between the philosophical ideas that could be mobilized in view of the pedagogical work. For that matters, we assume that the object of the interpretative social investigation is an action, the discursive act, which relies on interpretations of epistemic objects and symbolic practices; they are, therefore, always open to reinterpretations and change of perspective.

Considering the fact that we work with formative process for Portuguese teachers, both for undergraduate and graduate courses, our greatest interest is to point out possible ways to align argumentation teaching with discursive studies and to contribute with an unique vision of critical subjects formation. 
In order to present our point of view, we organized this article in two parts, namely: first, to study the types of arguments proposed by Perelman and Olbrechts-Tyteca (1971 [1958]), considering Foucault's concepts about the elements that bring about some impacts on discourse production; second, to propose a synthesis of the point of view argued in this work, to try to promote pedagogical actions that aim at developing argumentative practices around a controversial theme.

1. A vision regarding the argumentative procedures in the discursive composition

We know that, for Perelman (1982 [1977]), every argumentation implies a previous selection of facts and values, so his description reveals a particular way, a certain language, an insistence that varies according to the importance conferred by the subject for all this. The choice of elements, the mode of description and presentation, the value judgments, etc., shows a position. That is the reason why an affirmation at first sight may seem objective and impartial, but it express its character, mainly when confronted with other points of view, especially those of opposite direction. "Pluralism sharpens the critical sense" (PERELMAN, 1982 [1977], p. 34), unfolding that, in an argumentative situation, interaction takes place on several levels, particularly, between the arguments.

They are in constant interaction at more than one level: interaction between various arguments put forward, interaction between the arguments and the overall argumentative situation, between the arguments and their conclusion, and, finally, between the arguments occurring in the discourse and those that are about the discourse (PERELMAN; OLBRECHTS-TYTECA (1971 [1958], p. 460).

When considering also that every discourse is limited in time, the selection of arguments requires considering the pertinence and effectiveness of the choices aimed at obtaining the approval of the other to the presented ideas, the procedures of control and delimitation of the discourse, the external (interdiction and segregation) and internal (comment, authorship and alignment with the disciplines) procedures, benefit the rarefaction of the discourses (FOUCAULT, 1972). Furthermore, due to the fact that Foucault 
wants to overcome a classical view that understands discourse as a product of rhetoric and that restricts it to the meaningful structure of the text as well, the author proposes the analysis of the discursive formations that serve as grids "[...] in order to classify, to elicit differences and similarities, to visualize a certain order, whatever it may be" (ARAUJO, 2007, p.3, our translation).

In each formation, concepts are arranged in a certain way and used according to the field of knowledge and the way in which it relates, differentiates, whether or not it associates with other fields of knowledge. The same happens with the themes, they are invested by strategies that qualify or not institutions, techniques, social groups, obeying the concepts and uses that the discursive practice itself provides (ARAUJO, 2007, p.8, our translation).

When thinking about the organization of argumentative discourse, the differentiation and disposition of concepts, associated with the respective fields of knowledge, promote relationships that depend on discursive strategies. In summary, according to the principles of the New Rhetoric, the argumentative discourse produces some effects due to its input in a certain situation. Since the different elements of the discourse are interacting, the breadth of the argumentation and the order of the arguments raise many different problems and stimulate an analysis of the argumentative schemes that can be mobilized when one wants to persuade someone else. Perelman and Olbrechts-Tyteca (1971 [1958]) point out that argumentative statements can be analyzed in many different ways, according to the delimitation plans selected, so we decided to start from the classification and explanations organized by these authors to check how they could to be reinterpreted through the reflexive categories identified in Foucault's discursive studies.

Perelman and Olbrechts-Tyteca (1971 [1958]) insist that the argumentative techniques are at the service of the argumentative interaction. The term argumentative interaction is understood by Grácio (2011, p. 119-120, our translation) as the "[...] interaction between the arguers which roach their dissensions on a matter in question [...]". However, this is not a consensual point, since there are authors who extend the notion of interaction to relations that occurs due to "[...] a presence set outside the discourse with certain beliefs, attitudes and relations with the speaker or writer, and finds 
itself in an instance that requires the discourse has certain characteristics as an answer" (BITZER, 1968, p. 103) .This concept is proposed as a result of the expansion of the notion of audience which considers the written discourse, not exclusively the oral discourse.

The construction and the creation of the written discourse based on a projected audience is supported by Ong (1975) when analyzing the circumstances faced by free-lancers and students in writing exercises. These exercises compare the producer with real readers, who are outside the text and are represented, setting an invented audience. It is a "fiction," that is to say, the creation of a context in which "[...] readers may, in other words, be the 'audience' to varying degrees, or not at all. In this sense the audience may be said to exist in the text - if it can actually be said to exist anywhere" (PARK, 2012, p 249).

By making the census of the main argumentative techniques which one can resort to, Perelman e Olbrechts-Tyteca (1971 [1958]) present a both groups ranking: processes of connection and dissociation. The arguments consolidated between those who promote the connection process fulfill the role of consolidating different elements and enable the solidarity between the premises and ends, either by the discourse structuring or by the valuation (positive or negative) of those elements. Conceiving arguments as discursive events enables us, through the process of connection, to pay attention to regularity: "[...] an order in their successive appearance, correlations in their simultaneity, assignable positions in a common space, a reciprocal functioning, linked and hierarchized transformations [...]" (FOUCAULT, 1972, p. 37) in their dispersion.

On the other hand, the arguments resulting from the process of dissociation separate the elements considered as founders of a totality or, at least, of a supportive set in a certain system of thought, modifying even basic notions. Thus, it seems that it contributes to the disruption of the discourses, which, in Foucault's perspective, are intersecting practices, because "[...] discourse must be treated as a discontinuous activity, its different manifestations sometimes coming together, but just as easily unaware of, or excluding each other" (FOUCAULT, 1972, p. 229). 
In accordance with Grácio (2013a, p. 27), a study of the arguments is always schematic and arbitrary, but it can unveil the interactive dynamism of the argumentation, if there is a discursive evaluation, because the creation of themes allows articulating multiple dimensions promoting a trend that permits to go further than the analytical reasoning (based on logical criteria) and the analysis of the linguistic resources, bearing in mind the criticism of the discourse of one by the discourse of the other (GRÁCIO, 2013a).

From a psychological and logical perspective, we also emphasize that both the connection and the dissociation procedures are mutually implied, since every connection implies a dissociation and inversely:

[...] the same form which unites various elements into a well-organized whole dissociates them from the neutral background from which it separates them. The two techniques are complementary and are always at work at the same time; but the argumentation through which a datum is modified can stress the association or the dissociation which it is promoting without making explicit the complementary aspect which will result from the desired transformation [...] (PERELMAN; OLBRECHTS-TYTECA, 1971 [1958], p. 190).

The "two techniques" are complementary ("connection" and "dissociation"), then, show some possibilities of articulation of the thought and they are associated to the discursive practices that compose the knowledge of an era, that is to say, the effectively spoken statements and the functioning of the discourses indicate how the subject deals with exclusion procedures that affect the production of discourse, that is the reason why all the discourse is controlled, organized, and redistributed according to what can and cannot be said at a given time and place (FOUCAULT, 1972).

This constitutive interconnection between the processes, from the perspective of the New Rhetoric, favors the organization of three types of reasoning that are identified in groups: 1 . the almost-logical arguments; 2. those based on the structure of the real; 3 . those that established the structure of the real.

From here we begin to explain the characteristics of each type, based on the articulation that we are proposing between New Rhetoric and Foucault's ideas. The almost-logical arguments are the ones that are closer to formal thought because they have a logical or mathematical nature. However, we do not confuse them with logical arguments, in the strict sense, since they are 
not submitted to the rules of formal deduction, because they are related to theses of argumentative (non-formal) nature. In fact, the almost-logical arguments achieve persuasive force precisely by approximation to "[... ] a certain power of conviction, in the degree that they claim to be similar to the formal reasoning of logic or mathematics [...]" (PERELMAN; OLBRECHTSTYTECA, 1971 [1958], p. 193).

It is clear that they are subordinate to the organization of the disciplines which are defined by a domain of objects, a set of methods, a set of rules and definitions, techniques and instruments, a set of propositions considered true, constituting "[..] a sort of anonymous system, freely available to whoever wishes, or whoever is able to make use of them [...]" (FOUCAULT, 1972, p. 222).

In analyzing the discursive movement promoted by the subject when seeking to avoid contradictions, incompatibilities, tautology or when proposing inclusions of ideas, divisions, identities between people or situations, for instance, we notice a referral directed to a will of truth, situated, to be supported in an institutional support, which also reinforces and renews the discourse for a compact whole of practices (FOUCAULT, 1972).

The arguments established on the basis of a real structure are linked to the representations we make of concrete (daily) situations, the links recognized between objects, people, social circumstances and judgments admitted or those which we seek to promote. Solidarity among the elements is also the result of a will that establishes a symbolic link obtained through succession links, whose role is to connect an event to its consequences or causes, and through coexistence, that unite a person to his acts, a group to the others that belong either to an essence or to its manifestations (PERELMAN; OLBRECHTS-TYTECA, 1971 [1958]).

We observe that this kind of arguments disseminate a way of disposing or presenting discursive objects, that is, they indicate how a subject appropriates certain objects to talk about. They are "objects that do not preexist the knowledge, they exist as events, as what an epoch can say because of certain arrangements between the discourse and the non-discursive conditions," according to Araújo explanations (2008, p. 58, our translation), summing up the vision of Foucault (1972). 
In its turn, the arguments that ground the structure of the real are those supported by familiar situations, common places, which allows to establish a model or general rule applicable to different contexts from the selected resources of certain cases.

The connection between objects that are outlined in a knowledge and in social institutions is produced by a subject in a certain production situation, as well as in which other statements they are associated with, to identify the undertaken positions, the retakes and repetitions that delimit the discursive places. We understand, therefore, that the arguments, as statements built in a specific orientation, constitute units of the discourse formed by objects that exist in a bundle of relations with the circumstances (in a certain piece of knowledge). Discourse units are also formed by concepts, themes and strategies that are associated with discursive formations and practices and by the subject of the statement, determined by the place it occupies in the discursive materiality.

The statements are not ready and closed truths that allow a single "true" interpretation, they are events that must be understood in a continuity / discontinuity movement of thought, since ruptures can always be identified in alignment with the singularity of discursive formations. As Araújo (2007) explain:

The discourse has a historical, institutional support, a materiality that allows or prohibits its accomplishment. The subject of the discourse is not the person who performs an act of speech, neither the author of the text nor the subject of the proposition. The subject is the one who is able to use (almost always exclusively) certain statement by his training, due to the occupation of an institutional place, of his technical competence. The statement can be used or reused, to enter into frames and to transit around according to an interest, a practice; for instance, the statement [...] of the educator to assess the learning of a child, of the psychologist to detect behavior disorders (ARAÚJO, 2007, p. 7-8, our translation).

Due to the fact that we are aware that the discourse reveals different elements: "historical", “institutional”, technical and social, we propose to take into account both the argumentative procedures by connection and by dissociation, because they always indicate choices, characterized by the discursive formations, by the rules of appearance, by the conditions of appropriation, by the use and by the power (FOUCAULT, 1972). 
We also emphasize that the very choice of the premises and their way of formulation already has an argumentative value, because it is a preparation for the reasoning that constitutes the first step of a persuasive action. The selected fact, that is to say, what can be affirmed because it is accepted in a certain time and space, can also be considered an object of agreement, negotiation, consensus, identified through a process of argumentation (PERELMAN; OLBRECHTS-TYTECA, 1971 [1958]).

This point of view is in accordance with analyses that consider the arguments as statements that compose social practices constituted by language, which in our point of view is inseparable from the relations of power (social, political, economic, institutional and discursive practices) that delimit the speech. This movement of displacement, review and evaluation contributes to the identification of truths (truth-event, ritual truth, truthrelation of power, truth-method, truth-relation of knowledge, etc.) that situate the discourses as objects of knowledge-power.

It is important to emphasize that the arguments created by a process of dissociation of notions, which determines a more or less profound relocation of the conceptual data, also serve as a basis for the argumentation, by modifying its structures. This type of construction is usually less mentioned because it serves more specially for the analysis of philosophical thought, that is, of the thought that is intended systematically (PERELMAN, 1982 [1977]).

If the difference between connection and dissociation of notions depends on the acceptance of a primitive unity among the elements, "[... ] the dissociation of notions brings about a more or less profound change in the conceptual data that are used as the basis of argument" (PERELMAN; OLBRECHTS-TYTECA, (1971 [1958], p. 412). We agree with these authors and emphasize that, in a very controversial opposition, something that can be comprehended as a dissociation in a point of view may also seem distinctions between connected elements.

With respect to the "appearance-reality" pair, which is the basis of all kinds of dissociation, we emphasize that reality, as an event of knowledge, is a historical irruption dated and marked by complex determinations. It means that, in argumentation, reality is not considered as natural things, because it is constituted of culture, it is in fact an object constituted by language, which is 
associated with knowledge, it is developed historically and is tied to the processes of subjectivity.

As the expression subject at hand can be understood in several ways, it is better to clarify, from the explanations of Grácio (2013a), which can be understood by the combination of two parts. The notion of subject indicates

[...] a way of focusing (in order to delimit) and of referring to a potentially problematic space, but which refers not only to shared and common elements but also to different positions (considering the theme, a subject is a multidimensional category linked to problematicity) (GRÁCIO, 2013a, p. 39-40, our translation).

In the dimension of problematicity, then, the focus, the reference and the variety of positions make up a set of points of view and discursive positions, which start to circulate in society, through the expression of each subject. These procedures are always situational, so this notion is always flexible and requires different perspectives, which makes it possible to create intersections in the plane of the preferable.

Still according to Grácio (2013a, 42, our translation), we consider that the discursive expression of each one "[...] represents the actual presence of a discourse and a counter-discourse, that is to say, a situation of conflict and dissonance in which one discourse is criticized by another one". Therefore, an argument that serve as the basis for the real allows the subject to select aspects that can be taken as a reference, on account of the regularity with which they occur.

In school, in particular, despite the students' potential difficulties on the management of linguistic and discursive structures, to establish an argumentative dialogue through the argumentative techniques is always an effort that is worth undertaking, as it allows the students to compose analyses of reality and to mobilize various theorical and practical sources in an articulated manner.

When drawing attention to the school space, we are concerned with indicating ways for the teacher to map how it is possible to plan activities for teaching and learning argumentation, considering all the aspects previously discussed. 


\section{Challenges and possibilities to teaching of argumentation}

To compose a scenario for this discussion, we remind that the articulation between constitutive elements of argumentation in association with Foucault's ideas about the discursive dimension allowed us to realize that the process of teaching and learning of the argumentation requires an specific effort to look for alternatives that can support the pedagogical practices.

The teacher will need, then, to overcome the limits of teaching argumentative writing - which is very common in Portuguese language classes, especially in high school -, to aggregate the understanding of how persuasion can be built, which argumentative mechanisms can collaborate with this objective and how persuasive coherence is achieved, on the one hand; and knowing how to combine these investigations with coherent procedures that affect the production of discourses in society.

According to Perelman (1970 [1963]), the condition of teaching work production is very special, because, when the teacher adopts a stance directed to the teaching of argumentative techniques, he/she assumes a rhetorical position that can influence his audience ${ }^{1}$ (configured mainly by students and their relatives) in a very particular way:

The educator, without effort, is well regarded and enjoys confidence, as a nominee of the society which his audience belongs to. He mentions what is necessary to be admitted, as a qualified member, into a group which the audience looks forward to belong to. Not always he must demonstrate what he says: there is trust in his word; he does not have to adapt to his audience, it is his audience that adapts to him (Perelman (1970 [1963], p.108-109, our translation ${ }^{2}$ ).

In the face of this condition as a qualified and confident speaker in front of his audience, it is up to the teacher to recognize that the link between teaching activities and those of understanding argumentation and discourse

\footnotetext{
${ }^{1}$ We draw your attention to the fact that the audience is comprehended by Perelman; Olbrechts-Tyteca (1971 [1958], p. 19) "as the ensemble of those whom the speaker wishes to influence by his argumentation. Every speaker thinks, more or less consciously, of those he is seeking to persuade; these people form the audience to whom his speech is addressed".

${ }^{2}$ In the original : "L'éducateur a, sans effort particulier, l'oreille du public et sa confiance, comme représentant de la société à laquelle ce public appartient. Il énonce ce qu’il faut croire et dit ce qu'il faut faire pour être admis, comme membre qualifié, dans un groupe auquel l'auditeur aspire à appartenir. II ne doit pas toujours démontre ce qu'il avance: on a confiance en sa parole; il ne doit pas s'adapter à son public, c'est son public qui s'adapte à lui" (PERELMAN, 1970 [1963], p. 108-109).
} 
requires specific pedagogical planning, designed to promote the learning of argumentation through activities that may be varied, albeit guided by common principles, as we propose below.

Organizing a practical work around argumentation in a school environment may become even more challenging when the teacher is susceptible to external demands (legal requirements, family members, students themselves, etc.) and does not have a clear view of the bases of the pedagogical practices, according to reports of different professors participating in research and extension projects at the Federal University of Sergipe.

Hence, we consider important to highlight each principle in order to cooperate with the direction of the actions designed to the development of students' argumentative capacities (see AZEVEDO, 2016).

Table 1 - Interactional principle to guide the teaching of argumentation

\section{Principle 1}

To make the student capable of interacting with the other's discourse from the positions built around a topic under discussion.

\section{Argumentative focus}

To produce points of view that consider the plural ways of thinking and acting when approaching a subject in a game of perspectives.

\section{Discursive focus}

To take part in language practices in which statements integrate into discursive formations that specify the truth conditions of discourse.

Source: Prepared from Grácio (2010, 2011) and Foucault (1972).

First of all, it is necessary to clarify that the option to describe each principle separately regarding the argumentative and discursive focus stems from the need presented by many basic education teachers to understand the specificity of each one. The pedagogical work will integrate both focuses, but the distinction makes it possible to seek to guarantee teaching-learning situations that contemplate each of them.

As the objective of principle 1 is to create conditions for students to build their own positions in an interactional situation, that is, an argumentative situation - as Grácio describes in $2013 \mathrm{~b}$-, the argumentative focus is directed to the production of points of view, which requires a specific learning in the language plane: to be able to mobilize the voice of different subjects in the 
same statement. It is also necessary, in the discursive focus, to guide the perception that these voices are aligned with discursive formations, which intertwine (FOUCAULT, 1972).

In the interactional dynamics, a topic is transformed into the "subject in question", as proposed by Grácio (2013a) ${ }^{3}$, which reinforces the need for students to articulate their conceptions according to the participation of the interlocutors, whether they are face to face or assumed. Thus, there is a continuous evaluation of each other, allowing the permanent analysis of voices in dialogue.

Table 2 - Cognitive principle to guide the teaching of argumentation

\section{Principle 2}

To take the argument as a projective force of a vision of reality elicited by thematic processes. ${ }^{4}$

\section{Argumentative focus}

To create answers to the other one in an analytical process that guides the formulation of arguments and counter-arguments.

\section{Discursive focus}

To comprehend that the discursive positions come from power relations that guide how some can act on the actions of others.

Source: Prepared from Grácio (2010, 2011) and Foucault (1972).

Principle 2 emphasizes the cognitive aspects that allow the creation of arguments with a projective force and collaborate with the understanding of all the elements (discursive and non-discursive) that make up relations of power. This can be explored in the classroom through discursive exercises that can be carried out to solve situations that are particular to the reality of each school. Projective strength and power relations can be more effectively

\footnotetext{
${ }^{3}$ Grácio (2013a, p.39-40, our translation) explains that "[...] the term 'subject' is a term in common or common language and corresponds to a mental organization that is simultaneously a way of focusing (in the sense of delimiting) and referencing a potentially problematic space, but which refers not only to shared and common elements but to different positions (from the thematic point of view, a subject is a multidimensional category linked to problematicity). [...] It is a very flexible notion and raises positions and perspectives; and crosses the possible with the preferable [...]".

“'In question' [indicates], [...] adopting a dialogical and polyphonic conception of language, [...] that the opposition of voices is inherent in the argued discourse [...] (GRÁCIO, 2013a, p. 41, our translation).

4 "Thematization is a way of configuring subjects by perspectivizing them from the selection of certain considerations deemed relevant and whose admission guides the reasoning towards certain standards of evaluation, judgment and reasoning" (GRÁCIO, 2010, p. 75, our translation).
} 
observed when there is a concrete situation that requires deliberation between the parties involved, hence the recommendation that teaching practices be associated with real situations of language use.

In addition, we suggest grounding the methodology of work on the analysis of situations observed in society, since this always raises a divergence of judgments and it seems much more productive than resorting to activities supported by findings. Following Willard's suggestions (1979 apud Grácio, 2013a), we recommend the exchange of views in which polarization of positions is possible through the study of problematic and ethical issues.

Although the evaluation of the other is an aspect generally studied by the normative approach to argumentation, we can associate it with procedures that are supported by various criteria of rationality of arguments (see Grácio, 2013a).

Because of that, it is salutary to privilege moments that require the delineation of discursive positions and the conflict of understandings, so that the students can appropriate thematic procedures, through techniques of association and dissociation of arguments and also by the exercise of attitudes that can overcome the limits of the current circumstances, aiming to find ways for new practices of thought and politics.

In this view, students are invited to investigate whether there is an "acceptability system" organized around the issues being discussed. This theoretical-practical stance can be expanded by problematizing the "issues in question".

Through problematization, students have the opportunity to carry out the exercise of reflexivity, a type of reasoning that refers to the confrontation of the reasons chosen to justify the actions, the thematic orientations, the purposes that guide the discursive action, etc. and judging the value of each of these conditions of language production. It is not, however, an exercise restricted to the analysis of reasoning, for example, but to expand the understanding of the resources selected to thematize a subject, which provides an improvement in the ability to justify ideas.

We understand that this type of work can insert the student in argumentative situations in which they articulate different knowledge, values, positions, etc. in practices that promote identifying not only what is defended 
through support in different types of arguments, but also the ways of producing counter-discourses that allow confronting current perspectives.

Table 3 - Critical principle to guide the teaching of argumentation

\section{Principle 3}

To have the argumentative interaction as a privileged way to the development of the critical thinking that allows us to deal with the different kinds of the discursive articulations.

\section{Argumentative focus}

To improve the knowledge of processes, dynamics, ways and strategies that promote the evaluation of one's own thinking and the thinking of others.

\section{Discursive focus}

To analyze the discursive expression through statements that are not closed and unique structures, but discursive productions whose regularities, changes and networks are associated with specific times and places.

Source: Prepared from Grácio (2010, 2011) and Foucault (1972).

In this article, the critical perspective is assumed in the vision proposed by Foucault, that is, "criticism" associated with the notion of "experience", conceived as "as dominant structure and transformative force, as existing background of practices and transcending event, as the object of theoretical inquiry and the objective of moving beyond historical limits", as Lemke explains (2011, p. 26).

Foucault's view is elaborated based on the perception that criticism is not possible without considering the means and instruments for it to be exercised ${ }^{5}$. Therefore, in order to develop critical thinking, it is necessary, in addition to the theoretical study of argumentative strategies, to provide opportunities for students to confront each other in such a way that the evaluation of each other allows them to judge, deny, reject, condemn etc. ideas, which favors interaction based on rational, as well as subjective, patterns of reading reality.

It is important to recover that, according Lemke (2011), Foucault understand critique as an ethical-political gesture or an 'ethos', for this reason, it becomes relevant to provide conditions for students to oppose perspectives and analyze the resources that can be mobilized for the realization of

\footnotetext{
${ }^{5}$ According to Foucault (1997, p. 25), "[...] critique only exists in relation to something other than itself: it is an instrument, a means for a future or a truth [...]".
} 
positions in the speeches, which requires knowledge of the current social structures and available techniques, that is, in circulation in societies and, above all, those that are regular throughout history.

It is important to note, finally, that this set of positions removes the teacher from a central position and modifies his role with the students, once he departs from the obligation to transmit the values of a tradition and to form the reason of the students he works with, in order to enable those who are in formation to participate effectively in communicative situations around controversial issues, as Perelman (1970 [1963]) has already recommended more than fifty years ago.

\section{Conclusion}

Throughout this work, we made the commitment to problematize the knowledge about argumentation, in order not to desqualify, but to point out how the association to a discursive perspective, based on Foucault's studies, enables changing the comprehension of the relations systems which may seem homogeneous. With the New Rhetoric, we proposed to note that the use of one type of argument or another one not only shows a clipping of reality considering persuasion but the production of singular statements, from which we can identify continuity and discontinuity movements and the impact of power relations.

Considering all those points observed in this brief study, we realized that the complexity of argumentative and discursive operations, instead of making teaching practice impossible, encourages the teacher to direct pedagogical practices for the formation of critical subjects who intend to take in social transformation projects.

To sum up, we suggest the organization of didactic-pedagogical work that allows students of basic education to articulate positions about a subject in order to participate in processes of argumentative interaction, observing the conditions that delimit the discursive practices; to elaborate answers to the other, bearing in mind the processes of justification and analysis, as well as established power relations; to develop critical thinking through the use of different argumentative strategies and the analysis of the continuities and discontinuities in discourse. 


\section{References}

ARAÚJO, Inês Lacerda. Formação discursiva como conceito chave para a arqueogenealogia de Foucault. Revista Aulas. Dossiê Foucault, n. 3, 2007.

AZEVEDO, Isabel Cristina Michelan. Capacidades argumentativas de professores e estudantes da educação básica em discussão. In: PIRIS, Eduardo Lopes; OLÍMPIOFERREIRA, Moisés (Org.) Discurso e Argumentação em múltiplos enfoques. Coimbra: Grácio Editor, 2016. p. 167-190.

BITZER, Lloyd. The Rhetorical Situation. Philosophy and Rhetoric, n. 1, p. 1-15, 1968.

ERICKSON, Frederick. Métodos cualitativos de investigación sobre la enseñanza. In: WITTROCK, Merlin C. (Org.). La investigación de la enseñanza II. Métodos cualitativos y de observación. Barcelona: Ed. Paidós, 1986. p. 195-301.

FOUCAULT, Michel. The Archaeology of Knowledge and The Discourse on Language. Translated by A. M. Sheridan Smith. New York: Pantheon Books, 1972.

FOUCAULT, Michel. Politics of Truth. Edited by Sylvère Lotringer \& Lysa Hochroth. New York: Semiotext(e), 1997.

GRÁCIO, Rui Alexandre. Perspectivismo e argumentação. Coimbra: Grácio Editor $2013 a$.

GRÁCIO, Rui Alexandre. Vocabulário crítico de argumentação. Coimbra: Grácio Editor, 2013b.

GRÁCIO, Rui Alexandre. Do discurso argumentado à interação argumentativa. EID\&A - Revista Eletrônica de Estudos Integrados em Discurso e Argumentação, Ilhéus, 1, 117-128, 2011.

GRÁCIO, Rui Alexandre. Para uma teoria geral da argumentação: questões teóricas e aplicações didácticas. 434 f. Tese (Doutoramento em Ciências da Comunicação, área de conhecimento Semiótica da Comunicação). Instituto de Ciências Sociais. Universidade do Minho, 2010.

LEMKE, Thomas. Critique and Experience in Foucault. Theory Culture Society, v. 28, n. 4, p. 26-48, 2011.

ONG, Walter J. The Writer's Audience Is Always a Fiction. PMLA, v. 90, n. 1, p. 9-21, Jan. 1975.

PARK, Douglas B. The Meanings of “Audience”. College English, v. 44, n. 3, p. 247-257, mar. 1982. 
PERELMAN, Chaïm. The Realm of Rhetoric. Translated by William Kluback. Notre Dame, IN: University of Notre Dame, 1982 [1977].

PERELMAN, Chaïm. Éducation et Rhétorique. In: . Justice et raison. Travaux de la Faculté de Philosophie et Lettres de l'Université de Bruxelles. Bibliothèque de Philosophie, tomo XXV. 2. ed. Belgique: Presses Universitaires de Bruxelles. 1970 [1963]. p. 104-113.

PERELMAN, Chaïm; OLBRECHTS-TYTECA, Lucie. The New Rhetoric - A Treatise on Arumentation. Translated by John Wilkinson e Purcell Weaver. Notre Dame, IN: University of Notre Dame, 1971 [1958].

\section{Forma de citação sugerida}

AZEVEDO, Isabel Cristina Michelan de. Contributions from the new rhetoric and foucault's thought to the teaching of argumentative discourse. EID\&A - Revista Eletrônica de Estudos Integrados em Discurso e Argumentação, llhéus, n. 20, v. 1, p. 118-136, 2020. DOI 10.17648/eidea-20-v1-2698. 